\title{
Kosovo women's knowledge and awareness of human papillomavirus (HPV) infection, HPV vaccination, and its relation to cervical cancer
}

Pranvera Zejnullahu Raçi ( $\boldsymbol{\sim}$ pranvera.zejnullahu@uni-pr.edu )

Department of Obstetrics and Genecology, Hospital and University Clinical Service of Kosovo, University "Hasan Prishtina", Prishtina, Kosovo

Fitim Raçi

Department of Epidemiology, National Institute of Public Health of Kosovo, Prishina, Kosovo

\section{Teuta Hadri}

Department of Obstetrics and Genecology, Hospital and University Clinical Service of Kosovo, University "Hasan Prishtina”, Prishtina, Kosovo

\section{Research Article}

Keywords: human papillomavirus infection, HPV vaccination, cervical cancer, Kosovo

Posted Date: April 21st, 2021

DOl: https://doi.org/10.21203/rs.3.rs-404796/v1

License: (a) This work is licensed under a Creative Commons Attribution 4.0 International License. Read Full License 


\section{Abstract \\ Background}

The objective of this study, the first of its kind in Kosovo, is to determine the level of Kosovo women's knowledge and awareness of HPV infection, HPV vaccination, and its relation to cervical cancer.

\section{Methods}

This cross-sectional study was conducted from July to October 2018 at the Clinic of Obstetrics and Gynecology at the Hospital and University Clinical Service of Kosovo.

\section{Results}

Out of 800 questionnaires distributed, 645 were completed and returned ( $80.6 \%$ ). Only $0.5 \%$ of women were vaccinated against HPV. The majority of respondents $(66.4 \%)$ had no previous knowledge of HPV (human papillomavirus). Only $27.6 \%$ of respondents were aware that HPV is responsible for cervical cancer. About two-thirds $(70.1 \%)$ of respondents had never heard of the HPV vaccine, and only $24 \% \mathrm{knew}$ that the HPV vaccine can prevent cervical cancer.

\section{Conclusion}

The level of vaccination against HPV and the level of knowledge and awareness of HPV infection is extremely low. Higher education, younger age, and living in an urban area were favorable factors and correlated with awareness of HPV infection, vaccination against it, and its relation to cervical cancer. Based on this study, there is an immediate need for developing an educational program on HPV infection and the importance of HPV vaccination as a preventative measure against developing cervical cancer.

\section{Background}

Genital human papillomavirus (HPV) is one of the most frequent sexually transmitted infections. Although more than 200 genotypes of HPV have been identified, a group of 15 high-risk types are known as an essential factor for development of cervical cancer[1, 2] and also vulvar, vaginal, penile, and oropharyngeal cancers $[3,4]$.

The worldwide prevalence of HPV infection varies from 2 to 44\% [5]. Several meta-analyses indicate that the most prevalent HPV types are HPV16, HPV 18, HPV 31, HPV 52, and HPV 58 [6, 7] and HPV 16 and 18 are considered an etiologically determinant agent in over $71 \%$ of cervical cancer cases [6-8]. The prevalence of specific HPV types varies geographically, taking into consideration other cofactors, mainly 
socio-epidemiological ones. Recently, results were also obtained for Kosovo, where the overall HPV prevalence is $13.1 \%$, with HPV 16 as the most prevalent type [9].

In order to prevent HPV infection and thus reduce the risk of precancerous lesions and HPV-related malignancies, three types of vaccines are in use worldwide. The bivalent vaccine (Cervarix) targets HPV 16 and HPV 18. Quadrivalent Gerdasil covers HPV 16, HPV 18, HPV 6, and HPV 11, and the last vaccine to be licensed in US and Europe, mainly in high-income countries, is nonavalent Gerdasil 9, which offers protection against HPV $16,18,31,33,45,52,58,6$, and 11.

By 2017, 71 countries (37\%) had introduced the HPV vaccine into their national immunization program for girls, and 11 countries (6\%) had also done so for boys [10]. The WHO recommends vaccination of adolescents 9 to 13 years old prior to becoming sexually active and their potential exposure to HPV [11].

A study by Klug et al. showed that awareness of HPV across all populations is poor [12]. Many healthpromotion programs have sought to raise awareness of HPV vaccination, but evidence for such awareness is lacking [13].

As a small low-income country, Kosovo has not yet established any organized screening program for cervical cancer or vaccination against HPV. As already mentioned, the prevalence of HPV among Kosovo women is approximately at the same level as in other countries in the region, and so the risk for acquiring HPV-related malignancies is very high. Therefore it is necessary to introduce application of the HPV vaccine as well as the development of related health-promotion programs. Neighboring North Macedonia introduced primary vaccination against HPV in 2009, with a 40.1\% vaccination rate reported in 2013 [14].

\section{Methods And Material}

This cross-sectional study was conducted from July to October 2018 at the Clinic of Obstetrics and Gynecology at the Hospital and University Clinical Service of Kosovo. The methodology was based on questionnaires containing relevant indicators for each attribute. On average, the clinic serves about 200 hospitalized patients and provides outpatient treatment or advice to approximately 50 patients on a daily basis. This is the only tertiary clinic in Kosovo, and it provides medical services to women from across the country.

During the study, 800 structured questionnaires were distributed to women that were hospitalized or had consultations at the outpatient unit between July and October 2018. The pretested questionnaire had three parts. The first part elicited socio-epidemiological data, and the second part tested women's knowledge of HPV infection, the HPV vaccine, and its relation to cervical cancer. The third part of the questionnaire gathered information regarding women's knowledge and the rate of cervical cancer screening (the Pap test).

The questions were simple to answer, with only one correct response. The questionnaires were completed by respondents and then gathered at the collection point in nurses' offices in the departments at the 
clinic. Out of 800 questionnaires, 645 were completed properly and returned. The remainder were not filled out correctly or were not returned for final analysis. The overall response rate was $80.6 \%$.

\section{Statistical analyses}

\section{Method description}

Categorical variables were described by frequencies and percentages, and continuous variables by means and standard deviations. Multivariable logistic regression was used to study the association between demographic, social, and informative factors and awareness about the cause and prevention of cervical cancer, as well as the association between demographic, social, and informative factors and understanding the cause and prevention of cervical cancer. $P$-values $<0.05$ were considered statistically significant. Statistical analysis was performed using SPSS, v. 26.

\section{Results}

Out of 800 questionnaires distributed, 645 were completed correctly (80.6\%). Out of this number, 295 respondents (45.7\%) belong to the age group 18-25, followed by $187(29 \%)$ in the age group 26-33. Only four $(0.6 \%)$ respondents were older than 58 . Regarding their place of residence, 345 (53.5\%) of women lived in urban areas, and 300 (46.5\%) lived in rural areas. According to level of education, the respondents were divided into four different groups: $268(41.6 \%)$ had completed secondary school, $212(32.9 \%)$ had a bachelor's degree, 126 (19.5\%) had finished elementary school (or less), and only 39 (6.0\%) had a master's degree or higher level of education (Table 1). 
Table 1

Demographic characteristics of women included in the study.

\begin{tabular}{|lll|}
\hline Variable & $\boldsymbol{n}$ & $\%$ \\
\hline Residence & & \\
\hline Urban & 345 & 53.5 \\
\hline Rural & 300 & 46.5 \\
\hline Age & & \\
\hline $18-25$ & 295 & 45.7 \\
\hline $26-33$ & 187 & 29.0 \\
\hline $34-41$ & 103 & 16.0 \\
\hline $42-49$ & 34 & 5.3 \\
\hline $50-58$ & 22 & 3.4 \\
\hline$>58$ & 4 & 0.6 \\
\hline Education & & \\
\hline Elementary or less & 126 & 19.5 \\
\hline Secondary school & 268 & 41.6 \\
\hline Bachelor's & 212 & 32.9 \\
\hline Master's or PhD & 39 & 6.0 \\
\hline Total & 645 & 100.0 \\
\hline
\end{tabular}

As seen from Table 2, out of 645 respondents only $0.5 \%$ (3) of the women were vaccinated against HPV, whereas $99.5 \%$ (642) were not vaccinated.

Table 2

\begin{tabular}{|c|c|c|}
\hline \multicolumn{3}{|c|}{$\begin{array}{l}\text { Percentage of women ever } \\
\text { vaccinated against HPV }\end{array}$} \\
\hline Vaccinated & $n$ & $\%$ \\
\hline Yes & 3 & 0.5 \\
\hline No & 642 & 99.5 \\
\hline Total & 645 & 100.0 \\
\hline
\end{tabular}

The majority of respondents, $66.4 \%$ (or 428 of them) stated that they had no previous knowledge of HPV. One-third of them (215) knew of HPV, and two women (0.3\%) did not answer this question. When asked if 
HPV is a responsible factor for cervical cancer, only $27.6 \%$ (or 178) confirmed that they knew this; $7.6 \%$ responded "no," and most of them (64.7\% or 417) had no knowledge of this issue. Of the 645 women involved in our study, only $29.6 \%$ (or 191) had previously heard of the HPV vaccine, $70.1 \%$ had no prior information about the HPV vaccine, and only $0.3 \%$ did not answer the question (Table 3 ). 
Table 3

Women's knowledge and awareness of HPV infection, the HPV vaccine, and the connection between HPV, cervical cancer, and STIs.

\begin{tabular}{|c|c|c|}
\hline Question & $n$ & $\%$ \\
\hline \multicolumn{3}{|c|}{ Have you heard about HPV (human papillomavirus)? } \\
\hline Yes & 215 & 33.3 \\
\hline No & 428 & 66.4 \\
\hline No answer & 2 & 0.3 \\
\hline \multicolumn{3}{|c|}{ Is HPV responsible factor for cervical cancer? } \\
\hline Yes & 178 & 27.6 \\
\hline No & 49 & 7.6 \\
\hline Do not know & 417 & 64.7 \\
\hline No answer & 1 & 0.2 \\
\hline \multicolumn{3}{|c|}{ Have you heard about the vaccine against human papillomavirus? } \\
\hline Yes & 191 & 29.6 \\
\hline No & 452 & 70.1 \\
\hline No answer & 2 & 0.3 \\
\hline \multicolumn{3}{|c|}{ Does vaccination against HPV prevent cervical cancer development? } \\
\hline Yes & 155 & 24.0 \\
\hline No & 44 & 6.8 \\
\hline Do not know & 432 & 67.0 \\
\hline No answer & 14 & 2.2 \\
\hline \multicolumn{3}{|c|}{ Have you heard about sexually transmitted infections (STIs)? } \\
\hline Yes & 461 & 71.5 \\
\hline No & 110 & 17.1 \\
\hline Do not know & 73 & 11.3 \\
\hline No answer & 1 & 0.2 \\
\hline \multicolumn{3}{|c|}{ Do you know that STIs can be transmitted among partners? } \\
\hline Yes & 481 & 74.6 \\
\hline No & 35 & 5.4 \\
\hline
\end{tabular}




\begin{tabular}{|lcc|}
\hline Question & $\boldsymbol{n}$ & \% \\
\hline Do not know & 127 & 19.7 \\
\hline No answer & 2 & 0.3 \\
\hline
\end{tabular}

The association between several demographic, social, and informational factors and awareness of HPV or knowledge that HPV is related to cervical cancer was studied using multivariable logistic regression, and the results are summarized in Table 4. When controlling for other factors in the regression model, respondents with sexual experience are less likely to have heard about HPV (OR [95\% Cl]: 0.57 [0.32; 0.99]). Women with a university education had more often heard about HPV than women with a elementary education or less (OR [95\% Cl]: 8.33 [3.94; 17.63]), and women that were informed about HPV by nurses (OR [95\% Cl]: $2.75[1.25 ; 6.05])$, by teachers (OR [95\% Cl]: $2.46[1.39 ; 4.34])$, or via the internet (OR [95\% Cl]: 1.86 [1.17; 2.94]). Women with a university education were more frequently informed about the relationship between HPV and cervical cancer (OR [95\% Cl]: $6.89[3.13 ; 15.18]$ ) compared to those that were informed about the topic by nurses (OR [95\% Cl]: $2.78[1.28 ; 6.00]$ ) or/and via the internet (OR [95\% $\mathrm{Cl}]: 1.9$ [1.20; 3.01]). Women that were informed about HPV by friends knew about this relationship less often (OR [95\% Cl]: $0.39[0.16 ; 0.97])$. 
Table 4

Factors associated with HPV awareness and knowledge about the relation between HPV and cervical cancer (results of multivariable logistic regression).

\begin{tabular}{|c|c|c|c|c|c|c|c|c|}
\hline \multirow[b]{2}{*}{ Factor } & \multicolumn{4}{|c|}{ HPV awareness } & \multicolumn{4}{|c|}{ HPV knowledge } \\
\hline & No & Yes & $\begin{array}{l}\mathrm{aOR}(95 \% \\
\mathrm{Cl})\end{array}$ & $p$ & No & Yes & $\begin{array}{l}\mathrm{aOR}(95 \% \\
\mathrm{Cl})\end{array}$ & $p$ \\
\hline Urban & $\begin{array}{l}213 \\
(49.8)\end{array}$ & $\begin{array}{l}131 \\
(60.9)\end{array}$ & $\begin{array}{l}1.02(0.99 \\
1.05)\end{array}$ & 0.254 & $\begin{array}{l}234 \\
(50.2)\end{array}$ & $\begin{array}{l}110 \\
(61.8)\end{array}$ & $\begin{array}{l}1.02(0.98 \\
1.05)\end{array}$ & 0.310 \\
\hline $\begin{array}{l}\text { Mean age } \\
(S D)\end{array}$ & $\begin{array}{l}30.1 \\
(9.3)\end{array}$ & $\begin{array}{l}26.5 \\
(7.2)\end{array}$ & $\begin{array}{l}1.01 \\
1.55)\end{array}$ & 0.962 & $\begin{array}{l}29.7 \\
(9.3)\end{array}$ & $\begin{array}{l}26.7 \\
(6.8)\end{array}$ & $\begin{array}{l}0.99(0.64 ; \\
1.53)\end{array}$ & 0.947 \\
\hline $\begin{array}{l}\text { Sexual } \\
\text { experience }\end{array}$ & $\begin{array}{l}369 \\
(86.2)\end{array}$ & $\begin{array}{l}124 \\
(57.7)\end{array}$ & $\begin{array}{l}0.57(0.32 ; \\
0.99)\end{array}$ & 0.048 & $\begin{array}{l}388 \\
(83.3)\end{array}$ & $\begin{array}{l}106 \\
(59.6)\end{array}$ & $\begin{array}{l}0.66(0.38 ; \\
1.17)\end{array}$ & 0.153 \\
\hline \multicolumn{9}{|l|}{ Education } \\
\hline $\begin{array}{l}\text { Elementary } \\
(\%)\end{array}$ & $\begin{array}{l}120 \\
(28.0)\end{array}$ & $\begin{array}{l}13 \\
(6.0)\end{array}$ & 1 & & $\begin{array}{l}122 \\
(26.2)\end{array}$ & $\begin{array}{l}11 \\
(6.2)\end{array}$ & 1 & \\
\hline $\begin{array}{l}\text { Secondary } \\
(\%)\end{array}$ & $\begin{array}{l}213 \\
(49.8)\end{array}$ & $\begin{array}{l}46 \\
(21.4)\end{array}$ & $\begin{array}{l}1.63(0.80 \\
3.33)\end{array}$ & 0.182 & $\begin{array}{l}221 \\
(47.4)\end{array}$ & $\begin{array}{l}39 \\
(21.9)\end{array}$ & $\begin{array}{l}1.72(0.81 ; \\
3.68)\end{array}$ & 0.161 \\
\hline $\begin{array}{l}\text { University } \\
(\%)\end{array}$ & $\begin{array}{l}95 \\
(22.2)\end{array}$ & $\begin{array}{l}156 \\
(72.6)\end{array}$ & $\begin{array}{l}8.33(3.94 ; \\
17.63)\end{array}$ & $<.001$ & $\begin{array}{l}123 \\
(26.4)\end{array}$ & $\begin{array}{l}128 \\
(71.9)\end{array}$ & $\begin{array}{l}6.89(3.13 \\
15.18)\end{array}$ & $<.001$ \\
\hline \multicolumn{9}{|l|}{$\begin{array}{l}\text { Information } \\
\text { source }\end{array}$} \\
\hline Doctor (\%) & $\begin{array}{l}90 \\
(23.6)\end{array}$ & $\begin{array}{l}69 \\
(36.5)\end{array}$ & $\begin{array}{l}1.65(0.95 ; \\
2.84)\end{array}$ & 0.073 & $\begin{array}{l}99 \\
(23.9)\end{array}$ & $\begin{array}{l}60 \\
(38.5)\end{array}$ & $\begin{array}{l}1.57(0.91 ; \\
2.71)\end{array}$ & 0.107 \\
\hline Nurse (\%) & $\begin{array}{l}28 \\
(6.5)\end{array}$ & $\begin{array}{l}31 \\
(14.4)\end{array}$ & $\begin{array}{l}2.75(1.25 ; \\
6.05)\end{array}$ & 0.012 & $\begin{array}{l}31 \\
(6.7)\end{array}$ & $\begin{array}{l}28 \\
(15.7)\end{array}$ & $\begin{array}{l}2.78(1.28 ; \\
6.00)\end{array}$ & 0.010 \\
\hline Parents (\%) & $\begin{array}{l}14 \\
(3.3)\end{array}$ & $\begin{array}{l}19 \\
(8.8)\end{array}$ & $\begin{array}{l}1.97(0.75 \\
5.20)\end{array}$ & 0.169 & $\begin{array}{l}16 \\
(3.4)\end{array}$ & $\begin{array}{l}17 \\
(9.6)\end{array}$ & $\begin{array}{l}1.87(0.73 \\
4.77)\end{array}$ & 0.189 \\
\hline $\begin{array}{l}\text { Teachers } \\
\text { (\%) }\end{array}$ & $\begin{array}{l}37 \\
(8.6)\end{array}$ & $\begin{array}{l}63 \\
(29.3)\end{array}$ & $\begin{array}{l}2.46(1.39 ; \\
4.34)\end{array}$ & 0.002 & $\begin{array}{l}50 \\
(10.7)\end{array}$ & $\begin{array}{l}50 \\
(28.1)\end{array}$ & $\begin{array}{l}1.60(0.91 ; \\
2.79)\end{array}$ & 0.100 \\
\hline Internet (\%) & $\begin{array}{l}103 \\
(24.1)\end{array}$ & $\begin{array}{l}94 \\
(43.7)\end{array}$ & $\begin{array}{l}1.86(1.17 ; \\
2.94)\end{array}$ & 0.008 & $\begin{array}{l}117 \\
(25.1)\end{array}$ & $\begin{array}{l}80 \\
(44.9)\end{array}$ & $\begin{array}{l}1.90(1.20 \\
3.01)\end{array}$ & 0.006 \\
\hline Friends (\%) & $\begin{array}{l}41 \\
(9.6)\end{array}$ & $\begin{array}{l}18 \\
(8.4)\end{array}$ & $\begin{array}{l}0.45(0.19 \\
1.03)\end{array}$ & 0.059 & $\begin{array}{l}46 \\
(9.9)\end{array}$ & $\begin{array}{l}13 \\
(7.3)\end{array}$ & $\begin{array}{l}0.39(0.16 \\
0.97)\end{array}$ & 0.043 \\
\hline Media (\%) & $\begin{array}{l}60 \\
(14.0)\end{array}$ & $\begin{array}{l}46 \\
(21.4)\end{array}$ & $\begin{array}{l}0.75(0.42 ; \\
1.36)\end{array}$ & 0.345 & $\begin{array}{l}67 \\
(14.4)\end{array}$ & $\begin{array}{l}39 \\
(21.9)\end{array}$ & $\begin{array}{l}0.80(0.45 ; \\
1.45)\end{array}$ & 0.468 \\
\hline
\end{tabular}

The existence of a vaccination against HPV is better known to women with a university education compared to women with an elementary education or less (OR [95\% Cl]: $3.27[1.65 ; 6.45]$ ) and compared to those that were informed about vaccination by doctors (OR [95\% Cl]: $1.72[1.02 ; 2.88]$ ) or via the 
internet (OR [95\% Cl]: 2.23 [1.46; 3.42]) (Table 5). That vaccination prevents cervical cancer is better known to women with a university education (OR [95\% Cl]: $3.68[1.67 ; 8.13])$ and those that were educated about the topic by nurses (OR [95\% Cl]: 3.19 [1.42; 7.17]) or via the internet (OR [95\% Cl]: $2.37[1.49 ; 3.78]$ ). Women that received information from friends are less aware of this fact (OR [95\% Cl]: $0.33[0.12 ; 0.92])$. 
Table 5

Factors associated with awareness about HPV vaccination and knowledge about the relation between HPV vaccination and cervical cancer (results of multivariable logistic regression).

\begin{tabular}{|c|c|c|c|c|c|c|c|c|}
\hline \multirow[b]{2}{*}{ Factor } & \multicolumn{4}{|c|}{ HPV vaccination awareness } & \multicolumn{4}{|c|}{ HPV vaccination knowledge } \\
\hline & No & Yes & $\begin{array}{l}\mathrm{aOR}(95 \% \\
\mathrm{Cl})\end{array}$ & $p$ & No & Yes & $\begin{array}{l}\mathrm{aOR}(95 \% \\
\mathrm{Cl})\end{array}$ & $p$ \\
\hline Urban & $\begin{array}{l}230 \\
(50.9)\end{array}$ & $\begin{array}{l}114 \\
(59.7)\end{array}$ & $\begin{array}{l}0.99(0.96 ; \\
1.02)\end{array}$ & 0.509 & $\begin{array}{l}244 \\
(51.4)\end{array}$ & $\begin{array}{l}95 \\
(61.3)\end{array}$ & $\begin{array}{l}1.01 \\
(0.98 ; \\
1.05)\end{array}$ & 0.451 \\
\hline $\begin{array}{l}\text { Mean age } \\
(S D)\end{array}$ & $\begin{array}{l}29.9 \\
(9.1)\end{array}$ & $\begin{array}{l}26.5 \\
(7.4)\end{array}$ & $\begin{array}{l}0.98(0.66 \\
1.46)\end{array}$ & 0.923 & $\begin{array}{l}29.6 \\
(9.2)\end{array}$ & $\begin{array}{l}26.5 \\
(7.2)\end{array}$ & $\begin{array}{l}1.16 \\
(0.73 \\
1.82)\end{array}$ & 0.534 \\
\hline $\begin{array}{l}\text { Sexual } \\
\text { experience }\end{array}$ & $\begin{array}{l}373 \\
(82.5)\end{array}$ & $\begin{array}{l}121 \\
(63.4)\end{array}$ & $\begin{array}{l}0.75(0.44 ; \\
1.29)\end{array}$ & 0.306 & $\begin{array}{l}390 \\
(82.1)\end{array}$ & $\begin{array}{l}91 \\
(58.7)\end{array}$ & $\begin{array}{l}0.64 \\
(0.36 \\
1.14)\end{array}$ & 0.129 \\
\hline \multicolumn{9}{|l|}{ Education } \\
\hline $\begin{array}{l}\text { Elementary } \\
(\%)\end{array}$ & $\begin{array}{l}117 \\
(25.9)\end{array}$ & $\begin{array}{l}16 \\
(8.4)\end{array}$ & 1 & & $\begin{array}{l}115 \\
(24.2)\end{array}$ & $\begin{array}{l}11 \\
(7.1)\end{array}$ & 1 & \\
\hline $\begin{array}{l}\text { Secondary } \\
(\%)\end{array}$ & $\begin{array}{l}202 \\
(44.7)\end{array}$ & $\begin{array}{l}58 \\
(30.4)\end{array}$ & $\begin{array}{l}1.60(0.84 \\
3.03)\end{array}$ & 0.152 & $\begin{array}{l}222 \\
(46.7)\end{array}$ & $\begin{array}{l}35 \\
(22.6)\end{array}$ & $\begin{array}{l}1.26 \\
(0.58 \\
2.73)\end{array}$ & 0.554 \\
\hline $\begin{array}{l}\text { University } \\
(\%)\end{array}$ & $\begin{array}{l}133 \\
(29.4)\end{array}$ & $\begin{array}{l}117 \\
(61.3)\end{array}$ & $\begin{array}{l}3.27 \text { (1.65; } \\
6.45)\end{array}$ & $\begin{array}{l}< \\
0.001\end{array}$ & $\begin{array}{l}138 \\
(29.1)\end{array}$ & $\begin{array}{l}109 \\
(70.3)\end{array}$ & $\begin{array}{l}3.68 \\
(1.67 ; \\
8.13)\end{array}$ & 0.001 \\
\hline \multicolumn{9}{|l|}{$\begin{array}{l}\text { Information } \\
\text { source }\end{array}$} \\
\hline Doctor (\%) & $\begin{array}{l}96 \\
(24.4)\end{array}$ & $\begin{array}{l}62 \\
(35.2)\end{array}$ & $\begin{array}{l}1.72(1.02 ; \\
2.88)\end{array}$ & 0.040 & $\begin{array}{l}104 \\
(24.6)\end{array}$ & $\begin{array}{l}48 \\
(35.8)\end{array}$ & $\begin{array}{l}1.17 \\
(0.64 ; \\
2.12)\end{array}$ & 0.613 \\
\hline Nurse (\%) & $\begin{array}{l}33 \\
(7.3)\end{array}$ & $\begin{array}{l}26 \\
(13.6)\end{array}$ & $\begin{array}{l}1.76(0.85 \\
3.67)\end{array}$ & 0.129 & $\begin{array}{l}34 \\
(7.2)\end{array}$ & $\begin{array}{l}25 \\
(16.1)\end{array}$ & $\begin{array}{l}3.19 \\
(1.42 ; \\
7.17)\end{array}$ & 0.005 \\
\hline Parents (\%) & $\begin{array}{l}16 \\
(3.5)\end{array}$ & $\begin{array}{l}17 \\
(8.9)\end{array}$ & $\begin{array}{l}2.17(0.91 ; \\
5.22)\end{array}$ & 0.082 & $\begin{array}{l}20 \\
(4.2)\end{array}$ & $\begin{array}{l}13 \\
(8.4)\end{array}$ & $\begin{array}{l}1.18 \\
(0.45 ; \\
3.10)\end{array}$ & 0.744 \\
\hline $\begin{array}{l}\text { Teachers } \\
(\%)\end{array}$ & $\begin{array}{l}54 \\
(11.9)\end{array}$ & $\begin{array}{l}46 \\
(24.1)\end{array}$ & $\begin{array}{l}1.47(0.86 \\
2.50)\end{array}$ & 0.158 & $\begin{array}{l}51 \\
(10.7)\end{array}$ & $\begin{array}{l}47 \\
(30.3)\end{array}$ & $\begin{array}{l}1.91 \\
(1.08 ; \\
3.36)\end{array}$ & 0.026 \\
\hline Internet (\%) & $\begin{array}{l}110 \\
(24.3)\end{array}$ & $\begin{array}{l}87 \\
(45.5)\end{array}$ & $\begin{array}{l}2.23(1.46 ; \\
3.42)\end{array}$ & $\begin{array}{l}< \\
0.001\end{array}$ & $\begin{array}{l}119 \\
(25.1)\end{array}$ & $\begin{array}{l}76 \\
(49.0)\end{array}$ & $\begin{array}{l}2.37 \\
(1.49 ; \\
3.78)\end{array}$ & $\begin{array}{l}< \\
0.001\end{array}$ \\
\hline
\end{tabular}




\begin{tabular}{|c|c|c|c|c|c|c|c|c|}
\hline \multirow[b]{2}{*}{ Friends (\%) } & \multicolumn{4}{|c|}{ HPV vaccination awareness } & \multicolumn{4}{|c|}{ HPV vaccination knowledge } \\
\hline & $\begin{array}{l}40 \\
(8.8)\end{array}$ & $\begin{array}{l}19 \\
(9.9)\end{array}$ & $\begin{array}{l}1.15(0.57 ; \\
2.33)\end{array}$ & 0.692 & $\begin{array}{l}45 \\
(9.5)\end{array}$ & $\begin{array}{l}12 \\
(7.7)\end{array}$ & $\begin{array}{l}0.33 \\
(0.12 \\
0.92)\end{array}$ & 0.035 \\
\hline Media (\%) & $\begin{array}{l}66 \\
(14.6)\end{array}$ & $\begin{array}{l}39 \\
(20.4)\end{array}$ & $\begin{array}{l}0.81(0.46 ; \\
1.41)\end{array}$ & 0.453 & $\begin{array}{l}67 \\
(14.1)\end{array}$ & $\begin{array}{l}38 \\
(24.5)\end{array}$ & $\begin{array}{l}1.07 \\
(0.60 ; \\
1.93)\end{array}$ & 0.81 \\
\hline
\end{tabular}

\section{Discussion}

To the best of our knowledge, this is the first study of this kind conducted in Kosovo. The overall rate of women ever vaccinated against HPV is extremely low: $0.5 \%$, or only three women out of 645 included in the study. To date, Kosovo has no national programs for HPV vaccination and it has not promoted HPV vaccination. The prevalence of high-risk HPV genotypes among Kosovo women [9] is similar to that in other countries in the region, and the lack of a national screening program for cervical cancer in Kosovo corresponds to the great risk women have of acquiring cervical cancer.

Our results show that women's knowledge about HPV infection is poor because only $33.3 \%$ of women have any information about HPV, and the majority state that they have never heard of HPV. Some similar studies have been conducted worldwide, mainly assessing the knowledge of young adolescents and students, and they yielded different results. Much higher results were obtained in studies in many developed countries [13,15-17]. In a study of 204 women 16 to 23 years old attending a public outpatient gynecology clinic in Brazil, Moreira et al. found that $66.7 \%$ of women were informed about HPV [18]. However, a study in China showed even lower results, at 19.3\% [19].

Most of the women included in the study (72.3\%) do not know or think it is not true that HPV is a factor responsible for the development of cervical cancer. Other studies have showed similar results, such as a study in Nigeria [20], whereas a survey in Australia revealed that $66 \%$ of men and women know about HPV and cervical cancer [21].

Two-thirds of Kosovo women stated that they had never heard about the HPV vaccine, and only $29.6 \%$ of them have some information about the HPV vaccine. The percentage of women that know that the HPV vaccine can prevent the development of cervical cancer is even lower $(24 \%)$. These results are far lower than the rates reported in studies conducted in other countries $[17,18,21,22]$. The results of this study also confirm previous findings by other authors that a higher education level and younger age have an impact on the level of knowledge and awareness of HPV infection, vaccination, and its relation to cervical cancer $[22,23]$.

This study has some limitations. As a cross-sectional study, it may exclude causal relationships between various factors and results. Also, because the information was collected through questionnaires, there is a possibility of incorrect answers, which could lead to possible bias. Despite these possible limitations, 
the study had quite a high rate of response. Information was gathered from a large number of participants, making it a very representative sample.

\section{Conclusion}

Based on our results, it can be concluded that the level of vaccination against HPV in Kosovo is extremely low. The results also indicate that the level of knowledge and awareness of HPV infection, the HPV vaccine, and its causal association with cervical cancer is generally very low among Kosovo women. Having a higher level of education, living in urban areas, and being younger are favorable factors for having more information about HPV infection and the HPV vaccine.

Based on our study data, there is an immediate need for the development of a proper educational program about HPV infection and the importance of HPV vaccination as a preventative measure against the development of cervical cancer.

\section{Declarations}

Ethics approval and consent to participate: This study was performed in compliance with the Declaration of Helsinki and was approved by the Ethics and Professional Board of the Hospital and University Clinical Service of Kosovo (HUCSK), number 905 (dt. 06.08.2018). As in this study no personal data of the subjects have been taken (anonymous questionnaire used) there was no request from the above mentioned Ethical Board to have formal inform consent from the participants.

Consent for publication: Not applicable

Availability of data and materials: The datasets used and/or analysed during the current study are available from the corresponding author on reasonable request.

Competing interests: The authors have no conflicts of interest to declare.

Funding: No funding

Authors' contributions: Author PZR, FR and TH have given substantial contribution to design and conception of the manuscript, authors PZR and FR participated in acquisition, analysis and interpretation of the data. All authors have participated on drafting and revising the manuscript. All authors read and approved the final version of the manuscript.

Acknowledgments: The authors would like to thank the staff of Department of Gynaecology and Obstetrics in the Hospital and University Clinical Service of Kosovo for their technical assistance.

\section{References}


1. Walboomers JM, Jacobs MV, Manos MM, et al.; Human papillomavirus is a necessary cause of invasive cervical cancer worldwide. J Pathol. 1999 Sep;189(1):12-9.

2. Schiffman M, Castle PE, Jeronimo J, Rodriguez AC, Wacholder S. Human papillomavirus and cervical cancer. Lancet. 2007 Sep 8;370(9590):890-907.

3. zur Hausen H. Papillomaviruses in the causation of human cancers - a brief historical account. Virology. 2009 Feb 20;384(2):260-5

4. Gillison ML. Human papillomavirus-associated head and neck cancer is a distinct epidemiologic, clinical, and molecular entity. Semin Oncol. 2004 Dec;31(6):744-54. Review

5. Bosch FX, de Sanjosé S. Chapter 1: Human papillomavirus and cervical cancer-burden and assessment of causality. J Natl Cancer Inst Monogr. 2003;(31):3-13. Review

6. Bruni L, Diaz M, Castellsagué $X$, et al.; Cervical human papillomavirus prevalence in 5 continents: meta-analysis of 1 million women with normal cytological findings. J Infect Dis. 2010 Dec 15;202(12):1789-99.

7. Guan P, Howell-Jones R, Li N, et al.; Human apillomavirus types in 115,789 HPV-positive women: a meta-analysis from cervical infection to cancer. Int J Cancer. 2012 Nov 15;131(10):2349-59.

8. Li N, Franceschi S, Howell-Jones R, Snijders PJ, Clifford GM. Human papillomavirus type distribution in 30,848 invasive cervical cancers worldwide: Variation by geographical region, histological type and year of publication. Int J Cancer. 2011 Feb 15;128(4):927-35

9. Zejnullahu Raçi P, Hošnjak L, Poljak M, Lepej SŽ, Vince A. Pre-vaccination prevalence of high-risk human papillomaviruses (HPV) in women from Kosovo and their related sociodemographic characteristics. Ginekol Pol. 2018;89(9):485-494

10. WHO/ Immunization,Vaccines and Biologicals database, as of 31 March 2017. Available at http://www.who.int/entity/immunization/monitoring_surveillance/VaccinelntroStatus.pptx, accessed February 2017

11. Human papillomavirus vaccines: WHO position paper, May 2017, No 19, 2017, 92, 241-268 http://www.who.int/wer

12. Klug SJ, Hukelmann M, Blettner M. Knowledge about infection with human papillomavirus: a systematic review. Prev Med 2008;46:87-98.

13. Hendry M, Lewis R, Clements A, Damery S, Wilkinson C. "HPV? Never heard of it!": a systematic review of girls' and parents' information needs, views and preferences about human papillomavirus vaccination. Vaccine 2013;31:5152-67

14. Vaccination in Republic of Macedonia: Standards and Actual Trends. 2013. Available at http://www.medical-chambers.org/documents/Prof.DrKocoCakalaroski_Vaccination_Macedonia.pdf

15. Waller J, Marlow LA, Wardle J. The association between knowledge of HPV and feelings of stigma, shame and anxiety. Sex Transm Infect. 2007 Apr;83(2):155-9.

16. Dodd RH, McCaffery KJ, Marlow LA, Ostini R, Zimet GD, Waller J. Knowledge of human papillomavirus (HPV) testing in the USA, the UK and Australia: an international survey. Sex Transm 
Infect. 2014 May;90(3):201-7

17. Bowyer HL, Marlow LA, Hibbitts S, Pollock KG, Waller J. Knowledge and awareness of HPV and the HPV vaccine among young women in the first routinely vaccinated cohort in England.Vaccine. 2013 Feb 4;31(7):1051-6

18. Moreira ED Jr, de Oliveira BG, Neves RC et al.; Assessment of knowledge and attitudes of young uninsured women toward human papillomavirus vaccination and clinical trials. J Pediatr Adolesc Gynecol. 2006 Apr;19(2):81-7.

19. Yu Y, Xu M, Sun J et al.; Human Papillomavirus Infection and Vaccination: Awareness and Knowledge of HPV and Acceptability of HPV Vaccine among Mothers of Teenage Daughters in Weihai, Shandong, China. PLoS One. 2016; 11(1): e0146741

20. Makwe CC, Anorlu RI, Odeyemi KA. Human papillomavirus (HPV) infection and vaccines: knowledge, attitude and perception among female students at the University of Lagos, Lagos, Nigeria. J Epidemiol Glob Health. 2012 Dec;2(4):199-206.

21. Pitts MK, Heywood W, Ryall R et al.; Knowledge of human papillomavirus (HPV) and the HPV vaccine in a national sample of Australian men and women. Sex Health. 2010 Sep;7(3):299-303.

22. Marlow LA, Zimet GD, McCaffery KJ, Ostini R, Waller J. Knowledge of human papillomavirus (HPV) and HPV vaccination: an international comparison.Vaccine. 2013 Jan 21;31(5):763-9.

23. Tiro JA, Meissner HI, Kobrin S, Chollette V. What Do Women in the U.S. Know about HumanPapillomavirus and Cervical Cancer? Cancer Epidemiol Biomarkers Prev 2007;16(2).

\section{Supplementary Files}

This is a list of supplementary files associated with this preprint. Click to download.

- QuestionnaireEng.docx 